\title{
The Technology of Ethnography. An empirical argument against the repatriation of historical accounts
}

Thorgeir Storesund Kolshus

\section{(2) OpenEdition \\ Journals}

Electronic version

URL: http://journals.openedition.org/jso/6493

DOI: $10.4000 /$ jso.6493

ISSN: $1760-7256$

\section{Publisher}

Société des océanistes

\section{Printed version}

Date of publication: 15 December 2011

Number of pages: 299-308

ISBN: 978-2-85430-031-4

ISSN: 0300-953x

\section{Electronic reference}

Thorgeir Storesund Kolshus, "The Technology of Ethnography. An empirical argument against the repatriation of historical accounts », Journal de la Société des Océanistes [Online], 133 | 2e semestre 2011, Online since 31 December 2014, connection on 06 May 2019. URL : http:// journals.openedition.org/jso/6493; DOI : 10.4000/jso.6493 


\section{The Technology of Ethnography. An empirical argument against the repatriation of historical accounts}

by

Thorgeir Storesund KOLSHUS*

\begin{abstract}
Based on experiences from a longitudinal fieldwork engagement on Mota island in north Vanuatu, this article challenges the established opinion that old ethnographies shall be repatriated as a matter-of-course. Firstly, because they are far from factual but nevertheless are treated as such, since books are a different technology of knowledge from the orally transmitted versions of the past and consequently have a different sociocultural impact; secondly, because they in most cases will be an asset mainly to the educated elite; and thirdly, because reintroducing histories disturbs the distribution of knowledge in knowledge-based societies and could cause further social instability. I do not claim that the situation on Mota has a general validity throughout Melanesia. However, I remain unconvinced by one of the premises for the categorical repatriation argument: that the disputes over control over, and validity of, knowledge that characterise most Melanesian societies, on this particular point for some reason should be suspended.
\end{abstract}

KeYwords: Knowledge distribution, fieldwork, historical anthropology, social change, repatriation, education

\section{Paved with good intentions}

A few years ago, at a workshop that had brought together a number of regional specialists on Island Melanesia, I presented a paper that pointed

\section{RÉSUMÉ}

Basé sur les observations longitudinales d'un long travail de terrain dans l'ille de Mota au nord du Vanuatu, cet article conteste l'opinion établie considérant le rapatriement des données ethnographiques anciennes comme allant de soi. D'abord parce quelles sont loin d'être factuelles, mais sont néanmoins traitées comme telles, puisque les livres sont une technologie de connaissance différente des versions du passé transmises oralement et ont par conséquent un impact socioculturel différent; ensuite, parce quils seront dans la plupart des cas un atout principalement pour l'élite instruite ; et enfin, parce que la réintroduction d'histoires trouble la répartition des connaissances dans des sociétés basées sur la connaissance et pourrait aggraver l'instabilité sociale. Je ne prétends pas que la situation sur Mota a une validité générale partout en Mélanésie. Cependant, je reste dubitatif à l'égard d'un des présupposés fondant la thèse du rapatriement systématique: que les disputes portant sur le contrôle et la validité de la connaissance qui caractérisent la plupart des sociétés mélanésiennes, s'en trouvent, sur ce point particulier, suspendues pour une raison ou une autre.

MoTS-CLÉs : répartition du savoir, enquête de terrain, anthropologie historique, changement social, restitution, éducation

out some unfortunate consequences of returning old ethnographic accounts to their islands of origin, based mainly on my own experiences from a total two years of fieldwork on Mota island in the northernmost Torba Province of Vanuatu. 
By way of conclusion, I suggested that repatriation should be a question not only to the descendants of the people described: The researcher who was in possession of the comparatively ancient ethnographic works should scrutinize both the contents and possible outcomes before reintroducing what would be regarded as History returned. In short, I indicated that repatriation was no matter-of-course. The point came out in an even more cautious manner than I had initially planned, which made the ferociousness of the response from several of the anthropologically-minded historians present even more overwhelming: Repatriation was indeed a matter of course, I was obviously in the wrong, and apparently I also flirted with neo-colonial attitudes quite unbecoming an alleged advocate of Pacific people's interests. Taken aback by this charge, I admitted that my position as a self-appointed arbiter of what would and would not be beneficial to the Mota people indeed was awkward, but I still held that careful considerations should be made of the potential social impact from returning disrupted histories. Again, the argument fell among thorns, and I returned to my seat, slightly bruised. After the session, I spent some time pondering the claims of my critics, and, boosted by the support of some other colleagues, failed to find them wholly convincing. And in the years that have followed, during which I have engaged in extensive archive research that also includes the raw material for several of the relevant ethnographies, every now and then I have asked myself the question of whether the knee-jerk response from the historians really deserves its status as self-evident fact. Actually, I have come to believe even more strongly that repatriating ethnographic accounts is a hazardous enterprise that never should be taken lightly. The historians' case seems to rest on the mistaken assumption that ethnography is akin to history, thus in classic idealist fashion staring themselves blind at the message while ignoring the materiality of the medium. Ethnographies are not histories; they are books. And books are technology, not merely conveyor of their contents. Realising this simple fact will direct our attention to the materialists' emphasis on the sociocultural consequences of technological change - a ubiquitous historical feature that is manifest in everything from the rise of nationalism in the wake of the spread of print capitalism to decades of ill-informed attempts to bring about economic development without taking into consideration pre-existing social hierarchies and cultural values. Putting it simply, technology is never neutral; it will always impinge on relations of power. Based on my experiences with introducing the Motese to ethnographic descriptions of their ancestors' lives and ideas, as well as others' assessment of the effects my own writings have had on the island, I will in this article again challenge the notion that returning ethnographic accounts is a straightforward matter.

\section{Ethnography returned in the Age of Kastom}

In October 1996, after having spent two weeks in Vanuatu's capital Port Vila and another week in the gloomy "town" of Sola, the administrative centre of Torba Province, I finally found myself sitting in a fourteen feet open aluminium dinghy on my way to the hat-shaped island of Mota, in the company of five Mota men. Nobody uttered a word. Smiles were not reciprocated. After disembarking, I followed my fellow passengers up a steep path leading into a hamlet on a plateau, where I was shown to a chair far from where the others were sitting. A few minutes later, a small group of men came out of the forest, approached me and told me shyly to follow them. Our little entourage left the premises without saying goodbye to my companions from the dinghy, only to walk into a new and larger gathering of houses just a couple of hundred meters further inland. On the way, the men had started chatting, and when we entered the new village, the atmosphere was markedly lighter. I was approached by a mass of children, adults half-heartedly trying to hush them, and followed to a house at the edge of a large square. Here my backpack was put on the ground, and finally a young man approached to greet me. $\mathrm{He}$ told me, on a mix of Bislama and English that I later would recognise as the Bislama of the educated, that he was the chief of Lotawan village, that I was very welcome, and that they were glad to have me there. He shook my hand, and one by one the other men who had been standing by followed his example. Some of the women also came, and then the children, hurriedly and laughingly. I stuttered some words of thanks, and said that I was delighted to be there - which definitely was the truth, given the atmosphere in the boat and in the first village I had come to. These seemed like people I could relate to. Ever more people gathered round me, and assisted by the chief I told them about my family and where I came from, what I intended to do, how long I planned to stay, and that I got to learn about the island from a book written by a man named William Rivers, who almost ninety years earlier had spent several weeks interviewing John Pantutun of Veverao village onboard the mission ship Southern Cross. When I mentioned the name of John Pantutun, it caused much surprise and excitement, particularly among the men. The fact that John Pantutun had talked to an Englishman who later wrote a book about their customs and culture was un- 
known to the Motese. However, this bringing me to Mota almost one hundred years later did not surprise Fred of Lotawan village. His father Wilson Lolomaio had died just one month earlier, taking with him a vast reservoir of knowledge of history, genealogy and kastom that he had been eager to pass on but which they had failed to find the time to listen to. My unlikely journey from a hitherto unknown country of Norway with the purpose of studying the life and beliefs of the people on Mota, was to Fred an evident sign that I had been chosen by God. He associated this with the calling of Jeremiah ${ }^{1}$ and told this story to everyone who wondered why I had come. And indeed, this explanation is just as plausible as the serendipitous account I usually give: When reading on secret male cults in Melanesia (Allen 1967) for possible comparative ethnographies to my intended fieldwork on soccer, segmentary identities and masculinity in the Campagna region of southern Italy, I happened to come across a short notice on the island of Mota, where William Rivers in 1908 had recorded 77 different male cults among a mere 400 people. Since this coincided with a slight downturn in my enthusiasm for the Italy-project, I became quite intrigued by the possibility of using Rivers' ethnography as a historical contrast to my eventual findings. I rapidly pieced together a research proposal dealing with the distribution of secret knowledge as a basis for social stratification. Six months later, with a photocopy of Rivers' two-volume work in my backpack, I found myself on the very same island ${ }^{2}$.

Arriving, like I did, just one month after the death of Wilson, the living repository of Banks Islands' cultural history, and being familiar with histories of life on Mota in the old days that had been written down by an English man of science, were the reasons why the Torba Provincial Council and the Mota Vatealeale Council of Chiefs allowed me to do my research. Culture conservation was an explicit concern, both on Mota as well as on a provincial and national lev$\mathrm{el}$, and I was delighted to have the opportunity to provide something in return for the hospitality and friendliness they had shown me. People with a particular interest in the preservation of kastom saw my arrival as evidence to the young people of the value of kastom, and they regarded this as an opportunity to adjust or rectify some elements of kastom that had gone astray.

Although it would be a raving exaggeration to say that I was considered as some kind of messenger from a long gone past, the association with the prophet Jeremiah notwithstanding, balancing knowledge of previous history while retaining access to today's histories soon became a considerable methodological challenge. When I presented my research plan to the Provincial Council and the Vatealeale Council of Chiefs, I had emphasised the temporally comparative aspect of the project as particularly promising. This had guided the way people perceived the nature of my study, and after receiving a number of inquiries into how various practices really should be performed, I eventually discovered that I had been introduced to the public as someone who had come to inspect to what degree the Motese were living according to their kastom. Unsurprisingly, the majority of people in villages other than the one I was living in became very reluctant to answer my questions about anything even remotely relating to kastom, which would have amounted to voluntarily engaging in an oral examination.

The effects of this introduction were exaggerated by a methodological quirk. On the first full day of fieldwork, eager to get started, I engaged in that most emblematic of all anthropological endeavours, namely documenting genealogies. I sat down with Fred's son David, and asked him his name and the name of his wife. When I said in a half-asserting tone, «And your wife, she is your mother's brother's child?», his face turned red before he looked down and nodded. The question was of course shaped by the many examples of cross-cousin marriages I had come across in the anthropological literature. What I did not realise was that according to the logic of the Mota kinship system, a man's $\mathrm{MBC}$ is regarded as his own child. David's marriage was in other words highly inappropriate according to kastom, and the fact that I so easily could spot this unholy union suggested to him that I could read people's personal histories just by looking at them ${ }^{3}$. David's assessment of my capacities soon spread, and people understandably became even more reluctant to talk to me about anything apart from the most trivial matters. When he some months later laughingly told me what he initially had

1. «Before I formed you in the womb I knew you, before you were born I set you apart» (Jeremiah 1,5).

2. It is not my intention in this paper to assess the quality of Rivers' ethnography (but see Kolshus, 2007: 31-37, 2008: 59-62, forthcoming, for a closer scrutiny of some of his numerous misunderstandings), apart from seconding Raymond Firth's verdict: "[W]hile I admired the industry with which he had amassed so much of his data, from brief calls at villages and sessions with natives on the deck of the vessel I became increasingly convinced of the arid quality of his material, of its superficiality and lack of perspective.» (Firth, 1957 [1936]: xviii).

3. Codrington notes that the Motese have a clear understanding of blood relations, and hold that the blood of the father is part of the child. This makes a marriage between first cross-cousins unacceptable, since the «blood connexion with the father and the father's near relations is never out of sight» (Codrington, 1891: 29). Today, the Motese still oppose such unions, saying that "the blood turns bad» (o nara ti tatas). 
found me capable of, certain people's reactions towards my contact attempts suddenly became understandable. David's wholehearted laughter of course indicated how far from the truth he found his first conclusion to have been.

Meanwhile, in order to prove that it had been a correct decision to lodge me in their village rather than in the village of the men from the dinghy, some people in Lotawan started telling the most fantastic stories about my progress in kastom knowledge and how I taught them about their own lost kastom. Apparently, I had learnt the language in less than a week, even faster than the legendary John Coleridge Patteson, the first Bishop of Melanesia. They also insisted that I had caught on the rules of joking, poroporo, and respect, nommava, and other essentials of kastom so quickly that they had hardly anything left to teach me apart from the dances of the secret male Tamate associations, to which I would be introduced shortly. Since Lotawan was considered a kastom stronghold, this testimony did little to promote my discussions with people from other villages on matters relating to kastom. In retrospect, I also see the Lotawan presentation of me as an implicit claim to ownership. By intimidating most others from talking to me by emphasising my omniscience, they secured my continued association with the village $e^{4}$.

In addition to this came my status as a waetman, possessing the alleged superior knowledge that is attributed to all whities through their education system. I emphasised that the amount of knowledge I had of the world outside Mota was of no use to me now, since I knew nothing of any of the skills necessary to lead a proper Mota life: My edukesen, meaning formal school and university training, had prepared me for a wholly different existence, and I was amazed at the range of their knowledge and capacities. I also opposed the widespread opinion that edukesen created morally superior beings, a view that apparently had been encouraged by several of the handful of Motese who had undergone formal education beyond tenth grade. I preached that moral aptitude was visible in people's thoughts and actions rather than a consequence of edukesen. I also took the opportunity to underline that hardly any $w a-$ etman knew how to construct an airplane or survive on the moon. These points, repeated as often as possible, fell mostly on deaf ears. Rivers and I were part of the same exclusive system of knowledge, which was beyond the reach of all but a few Motese - some of whom understandably did not approve of my challenging the established hierarchy between educated and uneducated.

The factors mentioned above - the introduction of me as some kind of kastom bookkeep- er; the understanding that I possessed peculiar powers of introspection; the Lotawan people's desire to prove the Chiefs' Council's decision right; and the association between a European and edukesen - guided many people's perception of who I was and what I did. In order to reappear as approachable, I used every occasion to emphasise how little I actually knew of current Mota kastom and that I had come to study life on the island today, not whether one hundred year old stories did or did not live on. Since my first fieldwork project focussed on the stratifying potential of knowledge, I spent much time with my peers (unmarried young men), children and old women, in order to avoid being permanently linked to the handful of mainly male cultural experts. I also wanted to convey a picture of a likeable Regular Joe who took interest in all parts of Mota life and was interested in histories, not merely The History. Given that I had already experienced how little I was in charge of people's perception of me, this strategy was probably naïve and maybe also guided by my Scandinavian egalitarian habitus. Nevertheless, it seemed to work quite well, and my range of operation expanded until I had established close relations with several families in each village. In the process, I had detached myself slightly from the handful of (partly self-proclaimed) kastom men, and, after a while, it was no longer a matter-ofcourse that I should stay with them whenever I visited a village. Halfway into my first fieldwork, I moved with ease around the island and felt that the aura of omniscience had worn off. Access to various informants and arenas and the range of information had also drastically expanded, and the aspects of power discernible in the processes of the social distribution of knowledge proved particularly promising as a topic for analytic elaboration.

For the rest of my first fieldwork, and to some extent for the whole duration of the second, I engaged in similar methodological balancing acts. On Mota, as in most Melanesian societies, access to restricted knowledge is at the roots of the respect and esteem, nommava, pivotal to anyone desiring to be counted as a person of influence. However, knowledge should not be too esoteric, since its social significance depends on others accepting that a person's knowledge is actually worth having and, importantly, worth going through some trouble to obtain. In other words, while too liberally granting access to a piece of knowledge will lead to its inflation, making knowledge too inaccessible also undermines its social value. When rarely engaging in discussions where the parts of the expertise you allegedly hold could be relevant, people will start

4. Later, I have met similar stories from Mota. In his letters, Bishop Patteson shows frustration over how his attempts to make connections in other villages than Veverao, where the Mission station was located, were actively obstructed (Gutch, 1971: 132). 
questioning whether you actually possess that knowledge. This also reflected onto me, and created something of a methodological double bind-situation. Early in the fieldwork, I understood that an indiscriminate distribution of the information I had from Rivers would infringe on the rights of those who claimed knowledge of similar or related stories. Therefore, I evaded questions about how this or that was done before, usually by referring to the poor quality of Rivers' interpretation - an explanation that to a large degree is relevant. After a while, some of the kastom men started to question why I spent so much time with people who knew little about kastom and engaged in non-kastom activities such as soccer and volleyball. One of the most influential village chiefs was particularly critical, and he interpreted my silence on matters relating to kastom as an obvious sign of my ignorance and the neglect of the Lotawan people in teaching me the proper ways. By steering away from the Scylla of omniscience, I had come dangerously close to the Charybdis of triviality. The balance between communicating a desire to acquire knowledge and displaying increased proficiency needed to be restored. Consequently, in order to convince the kastom men that I indeed was interested in their stories and that the information they provided was not wasted on me, I would occasionally tell kastom stories that did not reveal secret knowledge or involve questions of origin, descent and land rights, as well as sharing what I knew about the world outside Mota.

\section{Rivers resurfaces}

The dog-eared photocopy of Rivers' two volumes remained in my hut for the first five months of fieldwork. It was not until I one day sat down with Joseph, the oldest man on Mota, that Rivers by proxy of his book again saw Mota daylight. Joseph showed clear signs of dementia on top of his having lost his hearing, but he had a very clear memory of his ancestry. And when he provided the name Rivlava for his father's father, I remembered this from Rivers (1914a: 27, see also Codrington, 1891: 38) and went to fetch the copy. Several others had gathered around us to listen to Joseph's story, and they looked perplexed when they realised that I actually had brought with me the book that I had been telling them about without showing it to them until now. But soon, Rivers' writings got the better of Peter, one of the bystanders. Almost without instructions, he accurately deciphered Rivers' ge- nealogies, and discovered that, as a matrilineal descendant of Taqale, he and his brothers were the rightful owners of an area Joseph and his sisters' sons had insisted was theirs, since Rivlala as Taqale's son only had patrilateral use-right to this land - which, as it happened, included the historic ground where the Melanesian Mission's school had been raised almost 140 years earlier. The full impact of Rivers' message, virtually from the grave, hit the growing crowd. "Ooh, all those coconut trees - with all that copra! ${ }^{5}$ reverberated. Peter did not even try to hide a gluttonous grin: All his worries about whether to afford sending his children to secondary schooling would soon be gone. The evidence he needed was right here in front of him. I attempted feebly to modify the status of Rivers' genealogy by pointing out how mistaken he had been on so many other counts, but no one paid anything but polite attention to me. The book spoke for itself: Solid, tangible proof of decades of uncustomary transfers of land that now, finally, would be rectified. To Peter, it was a godsend.

Troubled by this chain of events, I returned to my hut, Rivers in hand. Depriving a number of households of their only source of income was not in accordance with the "minimal impact"ideal I had been taught during anthropological method classes. My hopes that the book would be forgotten were soon proven quixotic. Ten days later, the village court fee had been paid and the case was heard in front of representatives of the Mota Council of Chiefs. Peter recited Rivers' genealogy with ease, adding the names of the proper heirs in the generations that followed. The members of the court agreed that this was a most interesting case, while declaring this a preliminary hearing since no representatives of the opposing party had attended in spite of being summoned. The chairman of the court suggested that maybe they had not realised the gravity of the situation. After adjourning, Fred mentioned that another case was about to be launched in the provincial court house in Sola. The disputed area was gigantic and included the land of the only governmental secondary school in the province as well as the Sola airfield and the Anglican vocational training centre. The immediate cause for the case had been the Anglican diocese's reissuing of an autobiographical booklet originally written in Mota one hundred years earlier by the first Melanesian priest George Sarawia (Sarawia 1996). Somewhere in the course of the twentytwo pages, George had declared himself a Mota man, a statement which according to Fred made him and the other Mota descendants of Sarawia the customary landowners also of his matriline-

5. Copra is the only cash crop on Mota and the sole means of income for virtually every Motese household. The island is a mere $10 \mathrm{~km}^{2}$ and the population 850 and rapidly growing, which means that land is a very scarce resource and mature coconut trees even more so. 
age's ground in the Sola area. They were now in the process of contacting all the concerned parties $^{6}$. Fred, much less gleeful than Peter had been some days earlier, held that Mota soon would be too small to support its growing population, and that cases like these were of great importance to the future of the island.

Some days later, I was approached by John, the only Mota man with tertiary education outside Melanesia and the only person with any proficiency in English. He reminded me of his great interest in cultural conservation and requested to borrow my copy of Rivers - so that, when he had finished reading it, he would invite me over for a talk. Realising that it would be futile to refuse, since the presence of the book had already been established, I agreed to lend it to him. Just one week later, he sent for me. When I asked him of his general impression, he expressed his surprise over the vastness of information and over a number of practices that he had never heard about, and, consequently, held must have been forgotten. My cautious suggestion that Rivers might have gotten it wrong in the first place was respectfully dismissed: It was there, in the book, how could it possibly be wrong? Thus corrected, I asked him what had surprised him the most, and he mentioned the kava prayer (1914a: 85), which had been long lost, and he emphasised the names Rivers provides for the two matrilineal moieties, Tatalai and Takwong (1914a: 22), which he had never heard mentioned ${ }^{7}$. The fact that members of the Takwong moiety according to Rivers' information were ignorant troublemakers had also been duly noticed, since John already had established that he belonged to the Tatalai division. When I was ready to leave, he said that he had not yet finished his reading, so he would like to keep the book for some more days. About one week later, I went for a short visit to one of the neighbouring islands, only to discover upon my return that John had left Mota to assume a teaching position, taking Rivers with him. Although immediately slightly annoyed, I did not think much about it until Peter again asked to see the book. When I explained that John had taken it with him when he left the island, Peter's face darkened but he did not say anything. Later I realised that the current landowners were supporters of John's political career. A clear majority believed that John had embezzled the book in order to make this crucial bit of evidence disappear. But Peter insisted that this was but a minor setback: I was still here, a scientist of Rivers' kind, and my testimony concerning the genealogy would be as convincing as presenting the book itself. When I begged to be excused with reference to what I suspected, and later established, was the uneven quality of Rivers' work, Peter took it with grace. The cat was out of the bag, he and several others had read how things really were, and at some point the smoking gun would be retrieved and he would begin his harvest. And thus ended the first episode of my cavorting with Rivers.

But some months before my return to Norway, I had come across a copy of Codrington's The Melanesians (1891), where he, among a range of other topics, introduces the concept of mana to the anthropological world. And although I did not have the time to study it properly until after I had left Mota, even a cursory reading left a lasting impression. Due to his numerous and prolonged stays on Mota and his many years as tutor, colleague and friend of people from Mota and the other Banks Islands on the Norfolk Island central school of the Melanesian Mission, where the Mota language was the medium of teaching and preaching (Hilliard, 1978: 34f.), the ethnography of Mota makes up more than a third of the book. I sent a copy of Codrington's work to the Anglican rector on Mota, with whom I had discussed my concern about the consequences of Rivers' return. When I completed my cand polit thesis a year and a half later (Kolshus 1999), this was also sent to the key informants and the cooperating bodies and organisations. The fates of these three very different ethnographic works are illustrative.

\section{Five years later}

While in Vila on my way to a second fieldwork in 2002, I accidentally met Johnstan, my FZS, on the street. We spent the afternoon updating me on recent developments on Mota, before going to a kava bar to meet the handful of diasporic Motese in Vila, joined by some other Banks Islanders. There I was confronted with rumours that I had been part of the Norwegian team during the 1998 Soccer World Cup: Someone had apparently seen me on a video from one of the games. I managed to convince them that rumours of any such involvement, although flattering, were untrue. To lift the air of disillusionment, Johnstan felt it apposite to highlight another alleged achievement of mine; namely

6. When I left in 2003, the case was still stuck in initial proceedings. Fred and his companions, who included representatives of the Anglican diocese, blamed the court clerk, a member of the Pentecostal denomination Assemblies of God, for wilfully obstructing its progress.

7. Rivers probably mistook names for two tarañiu matrilineages as representations of the moieties. Codrington, much better informed on these issues because of his twenty-five years working with Banks' Islanders and his language proficiency, states: «In neither the Banks' [sic] Islands nor the New Hebrides is there a name to distinguish the [moiety] division or kindred» (1891: 24). 
how I had revitalised kastom by teaching them the kava prayer, which now had been retrieved throughout the Banks Islands. My vain attempt to modify the part I actually had played in this endeavour was ignored as decorous modesty, since without me there would have been no kava prayer - and the men hailed the new solemnity with which this formerly highly mundane ritual was now performed. Still embarrassed, but also fascinated by the convolute nature of even such a temporally shallow origin story - to which I had full insight of the initial proceedings - I left for Mota the day after. And during a number of welcoming ceremonies the following week, most of which included the kava prayer, I was confronted with my position as a kastom caretaker. Even though a few appreciated the fact that they had the books rather than me directly to thank for this rare reversal of what was generally seen as a steady deterioration of kastom, I had been instrumental in the process. Interestingly, they wrongfully pointed to the Codrington book I had sent the rector as the source rather than the lost copy of Rivers. But even though the few phrases I managed to identify through the inarticulate recitation of the prayer far from matched those rendered by Rivers, I settled for the Roman Catholic principle of est opera, operato, and acquiesced with my role as a cultural revivalist.

Far more fascinating was a novelty that people did not regard as such: The Motese now widely referred to the moieties as Tatalai and Sakwong (sic). Even my adoptive father Paul and his elder brother Fred, who were consider by most as kastom experts, used these names as if they had been around forever. When I cautiously asked why I had never heard the moiety names during my first fieldwork, Paul and Fred expressed their surprise over this apparent flaw in my kastom training. I chose not to remind them that their classificatory brother John, who also was well versed in the ways of kastom, five years before had insisted that the information was new to him. Graciously, the unfavourable traits that Rivers' informant associated with the Sakwong moiety, to which I belonged, had been left out in the process of reappropriation. This collective display of structural amnesia was both intriguing and puzzling, and I spent much time pondering the consequences for my analytical approach to cultural continuity and historical depth. The flexible genealogies of the Tiv of Nigeria, described by the Bohannans (for instance P. Bohannan, 1953), suddenly came to mind, along with a judgment by Codrington:

"In the Melanesian islands, with one notable excep-
tion, the enquirer seeks in vain for antiquity" (1891: 47)
Previously, I had found this quote far too rigid, but now I was no longer certain. Reality soon called, though, as I was approached by Peter, who asked to have a look at the buk tape kastom, the kastom book, by which he referred to Rivers. Wiser from harm, I did not bring with me either Rivers or Codrington this time around, and when questioned about the genealogy that had caught his attention five years earlier, I truthfully admitted that I could not remember the details. Obviously better equipped, he straightforwardly recited the thirty-odd names and relationships from Rivers, and added the twenty persons that connected Rivers' present with ours. But I repeated my unwillingness to corroborate his version. Peter left, frustrated ${ }^{8}$. Some days later, I went to a village on the other side of the island to visit my mother's mother Hansen Rōnuń. When I got there, she was fuming. Her friend and joking partner Zebalon had come by earlier that day and told her that Peter and some other men were about to initiate a land court case to claim an area that belonged to him and Hansen's husband, Robinson. Rumours had it that they would write me a letter demanding that I handed over a copy of Rivers' genealogy. Before I could respond, my easily agitated grandmother made it clear that she would not allow me to hand over any such thing. She could not read English, she said, but she knew the histories of land transfers, $\bar{o}$ matesala ñañ tape tanō, and of people's access to it better than anyone, and she would not have it that these men could use a book to gain property that did not belong to their lines. When I finally got a word in, I repeated what I had told Peter: Rivers was no ultimate authority, and if people would go to court over land issues, they should settle the case as they always had, by basing their claims on knowledge of lines of descent in the presence of an independent arbitrator. Thus reassured, Hansen was all smiles again. And even though mention was made of the book from time to time, I was no longer approached by anyone who was inquisitive about specific contents or its whereabouts.

\section{Fetishising the Written}

But my grandmother's apprehension for the effects of Rivers' book as evidence was as genuine as it was perceptive. This old woman, recognised by everyone on the island as an oracle of things past, had come to realise a crucial trait of her fellow Motese, and indeed probably of humankind: We are all like the disciple Thomas. Things we can see and touch outweigh that which we 
only hear. As objects, books are fetishised and become more potent than the sum of their contents would suggest. Materiality overshadows the intangible. Hansen knew how the Motese clung to their worn copies of the Mota Book of Common Prayer whenever they went to church - or indeed simply torn chapters of any piece of printed material they had access to, be it a schoolbook or even pamphlets from the Seventh Day Adventists, their ultimate Others. Even if these were never read, they sent a clear signal on the substance of the Written. In this respect, they copy the reverence that is shown to the $\mathrm{Bi}$ ble by the clergy during the celebration of Mass every Sunday and other Holidays in the AngloCatholic Mota Church. It is matter that matters. On this awareness of the value of the written paper, Hansen is seconded by a range of incidents and arguments throughout the history of modern anthropology. When all his frustrations became too overwhelming, Malinowski sought refuge and escape in his books for days, and even weeks, on end, and the books confirmed that he belonged elsewhere and that eventually there would be an end to it all (Malinowski, 1967); Robert Codrington, after he left Melanesia in 1887 to live on for almost forty years in England, had in the letters he received from his Melanesian friends solid proof of a continued relationship with people he loved yet knew he would never see again (Kolshus, 2011); Jean Briggs, temporarily ostracised by her Inuit hosts, found consolation in her productivity, evidenced in the rising pile of typewritten paper (Briggs, 1970); for the contributors to the anthology Fieldnotes (Sanjek, 1990), fieldnotes were tokens of professional identity, but also physical manifestations of shortcomings, anxiety, and despair; and in his closing note on a discussion with Mary Patterson, Knut Rio suggests that she has essentialised her own field material and failed to consider the possibility of change in the twenty-five years between her fieldwork and his (Rio, 2007, see also Patterson, 2006). And according to Canadian journalist Charles Montgomery, my own work already had an effect similar to that of Rivers and Codrington outlined above. He spent a week on Mota in 2001 doing research for an award-winning non-fiction book on the Melanesian islands, travelling in the wake of his greatgrandfather, who had been caretaker-bishop of Melanesia in 1892 (Montgomery, 2006). While there, he got an opportunity to witness the impact of my first thesis, which had arrived by mail two years earlier. His reflections aptly illustrate my argument:

"On Mota I realized that European accounts of the island's kastom always seemed to carry the most weight. Thus Hansen Ronung, whose job it was to sing her way through Motese history, could be corrected and humbled with a few anecdotes from Codrington's Melanesians [sic], and when the Motese argues about modern culture and rituals, their disputes were now arbitrated by whoever was holding the tattered copy of Thorgeir Kolshus's University of Oslo thesis. Was Kolshus an expert on Motese culture? The islanders evidently thought so. Before Alfred and his brothers drank kava, one of them always said a little prayer and spilled a drop of it on the ground. But the men admitted that it wasn't their fathers who had taught them that prayer. It was Kolshus. And he, it turns out, picked up that gem from anthropologist W. H. R. Rivers's 1914 book The History of Melanesian Society. Alfred had told me that he thought Kolshus's big idea, the one about the Motese having two souls, was just plain wrong. His words faded amid a haze of kava, conversation, and guitar strumming; and they will be transmuted with every year, as conversations do. But Kolshus's versions of kastom will live on, unchanged." (Montgomery, 2006: 157-58)

Although somewhat exaggerated to enhance readers' suspense, the passage gives much food for though. It also brings to the fore the relation between ethereal, and frequently contested, oral history and the tangible and unequivocal written - which is not exposed to the wear-and-tear of social processes of cultural transmission but only to that of physical deterioration ${ }^{9}$. In a society where traditions have been passed on orally or by display, it is a truism that literacy does not correlate with knowledge of kastom. Besnier argues that ability to read and write is not an absolute but rather a continuum, and that this «steeped literacy» (Besnier, 1995: 171) serves as a principle of stratification. His description befits the Mota case, with one notable modification: Literacy is not a measure of relative reading and writing skills, but is a consequence of being counted among those who possess edukesen (Kolshus, 2007). In other words, it is rather a question of imagined literacy. Consequently, should a kastom expert without edukesen raise his or her voice against an exegesis of Rivers', Codrington's, or my own, scholarly ethnographies - notwithstanding whether they be accurately described and understood by us in the first place - these objections are easily discounted with reference to the opponent's lack of edukesen, even though his or her reading is more in line with the actual contents. Therefore, those who benefit the most from the repatriation of ethnographies are the ones who successfully can claim association with both kastom and edukesen, thus combining the virtues of the past with the promises of future material development (Kolshus, 2007: 31922). This handful of people, all men, are believed when they maintain that they have a good grasp of the Written, and can therefore assume the po-

9. Which, admittedly, sets in quickly under climatic conditions that also have discouraged the development of a tradition for material preservation. 
sition as gatekeepers when debates arise, thus sidelining the kastom-savvy but uneducated men and women. Incidentally, these few were also the most prominent party-political players on Mota, who all had held public office on provincial or even national level. The returned ethnographies strengthened their positions vis$\grave{a}$-vis the others.

\section{History, Ourstory, Theirstory}

On Mota, books are regarded as objective descriptions of how things really were, detached from the imperfections of personal and collective memory. Consequently, books are a new technology of knowledge, which someone possesses and is able to access while others are left with the lesser valued tools of mere memory. My fellow melanesianists' insistence on bringing back ethnographic descriptions adds weight to this fetish of the Written. I do not suggest that my colleagues believe in the accuracy of old accounts. Quite the contrary, I believe they trust people to assess the shortcomings as well as the virtues of these returned histories. But this commendable, and apposite, conviction of the universal capacities of mankind turns a blind eye to existing hierarchies of power: Some are better positioned than others to turn new elements to their benefit. My colleagues' standpoint also seems to reflect the notion that cultural preservation is a common concern that sidelines the processes of differentiation and contestation that permeate virtually every other social domain. This model is far too harmonious to fit the actualities of Mota society, and I would be surprised if it adequately described more than a fraction of other Melanesian societies in which access to restricted knowledge is a key principle of social stratification. These points are tangential to Keesing's argument on how kastom ideologies serve the educated and urban elite, who can enjoy the fruits of both worlds, while effectively obstructing the path that leads to their privileged existence, by their hegemonic influence over what constitutes a valued village life (see for instance Keesing, 1989). In Steven Lukes' terms, they represent the third dimension of power, "the capacity to secure compliance to domination through the shaping of beliefs and desires, by imposing internal constraints under historically changing circumstances." (2005: 143-44) In short, they control the "power to mislead» (op. cit.: 149).

As will now be clear, I remain unconvinced by the historians' position, given the general understanding of the plasticity of storytelling in societies with no tradition for written history. The technology of ethnography hands the powers of definitions to the educated elite. If the intention was kastom preservation, the result of repatriating the works of Rivers, Codrington, and me, is at best a failure to meet the target. But I fear that it has emasculated the old, and more democratic, oral medium of knowledge transmission, and cemented a hierarchy in which access to the higher echelons will remain out of reach for all but a few.

It is not consider good academic writing practice to end an argument with open questions. But in the spirit of challenging the status of the Written, I nevertheless choose to emphasise some dilemmas that follow from my discussion. First, it is a truism pointed out by the reader-response tradition of literary theory that once published, authors lose control over the reception, interpretation and use of our work. But when does our responsibility for its consequences end? Second, as experts on social processes, we should be better positioned to assess the eventual impacts of new technologies, such as ethnographic accounts. So how can one engage in the reappropriation of historic material without assuming a neo-colonial stance that lends authority purely to formal education? Third, can one really say that an ethnographic like Rivers' account is an ethnography of Mota, when it clearly represents the exoticising gaze of a post-Victorian diffusionist anthropology that is just at telling of Rivers' historic and geographical background as it is of the lifes, beliefs and concerns of the Motese in 1908 - and even depending almost solely on one informant? And from this follows my fourth and final concern: At what point does an ethnograhic present turn irreversibly into an ethnographic past, for which we can longer presume the cultural continuity that has been part and parcel of anthropological thinking throughout the history of the discipline (Robbins 2007)?

\section{BIBLIOGRAPHY}

Allen M.R., 1967. Male Cults and Secret Initiations in Melanesia, Melbourne, Melbourne University Press.

BesNier Niko, 1995. Literacy, emotion, and authority, Cambridge, Cambridge University Press.

Briggs Jean L., 1970. Never in Anger, Cambridge, MA, Harvard University Press.

Bohannan Paul, 1953. Concepts of time among the Tiv of Nigeria, Southwestern Journal of Anthropology 9, pp. 251-262.

Codrington Robert Henry, 1891. The Melanesians, Oxford, Clarendon Press.

FirTh Raymond, 1957 [1936]. We, the Tikopia, Boston, Beacon Press. 
GuTCH John, 1971. Martyr of the Islands, London, Hodder and Stoughton.

Hilliard David, 1978. God's Gentlemen. A history of the Melanesian Mission 1849-1942, St. Lucia, University of Queensland Press.

Keesing Roger M., 1989. Creating the past: Custom and identity in the contemporary Pacific, The Contemporary Pacific vol 1, pp. 19-42.

Kolshus Thorgeir S., 1999. Purism, Syncretism, Symbiosis. Cohabiting traditions on Mota, Banks Islands, Vanuatu. Oslo, University of Oslo, available online http://anglicanhistory. org/oceania/kolshus1999.pdf.

-, 2007. We, the Anglicans. An ethnography of empowering conversions in a Melanesian island society, Oslo, Unipub.

—, 2008. Adopting change: relational flexibility as vice and virtue on Mota Island, Vanuatu, Pacific Studies 31, pp. 58-86.

_, 2011. Letters from homes. Maintaining global relationships in the Victorian age, in Ingjerd Hoëm and Reidar Solsvik (eds), Identity Matters, Oslo, Kon Tiki Occasional Papers 12, pp.51-62.

—, 2011. Forthcoming (2012). House upon Pacific sand? W.H.R. Rivers and his 1908 ethnographic 'survey work', in Cato Berg and Edvard Hviding (eds), The ethnographic experiment: Rivers and Hocart in the Solomon Islands, 1908, Oxford and New York, Berghahn Books.

Lukes Steven, 2005. Power. A radical view, Hampshire and New York, Palgrave Macmillan.

Malinowski Bronislaw, 1967. A Diary in the Strict Sense of the Term, London, Routledge \& Kegan Paul.

Montgomery Charles, 2006. The Shark God, New York, HarperCollins.

Patterson Mary, 2006. Agency, kinship and history in North Ambrym, Journal of the Royal Anthropological Institute I2, pp. 2 I I-I 9.

Rio Knut Mikjel, 2007. The Power of Perspective, New York and Oxford, Berghahn.

Rivers William H., 1914a-b. The History of Melanesian Society vol 1 and 2, Cambridge, Cambridge University Press.

Robbins Joel, 2007. Continuity thinking and the problem of Christian culture. Belief, time, and the anthropology of Christianity, Current Anthropology 48, pp. 5-38.

SANJeK Roger, 1990. Fieldnotes, Ithaca and London, Cornell University Press.

Sarawia George, 1996. They Came to My Island, Port Vila, Pars Printing. 